\title{
Sistem Pendukung Keputusan Menentukan Status Karyawan Kontrak Sales Promotion Girl Menjadi Karyawan Tetap dengan Metode Simple Additive Weighting
}

\author{
Rudi Hartoyo \\ STMIK Budi Darma Medan, Jl. Sisimangaraja No.338 Simpang Limun, Medan, Indonesia \\ rudihartoyo91@gmail.com
}

\begin{abstract}
Abstrak. Dalam menyeleksi dan menentukan Karyawan kontrak seperti Sales Promotion Girl (SPG) untuk menjadi karyawan tetap di salah satu perusahaan, masih terlihat kurang tepat, karena penilaian dan perhitungan hasil dari tes dilakukan secara manual, sehingga kemungkinan kesalahan dalam memberikan hasil akhir dari penyeleksian. Oleh karena itu, dirancanglah sebuah Sistem Pendukung Keputusan yang dapat menentukan karyawan kontrak SPG menjadi karyawan tetap yang dapat membantu perusahaan dalam memilih karyawan yang tepat. Sistem Pendukung Keputusan merupakan bagian dari sistem informasi berbasis komputer yang biasa digunakan untuk mendukung pengambilan keputusan pada suatu organisasi atau perusahaan. Sistem pendukung keputusan ini dirancang menggunakan metode Simple Additive Weighting (SAW) untuk menghitung hasil dalam menentukan karyawan kontrak SPG menjadi karyawan tetap. Sehingga, dalam proses penyeleksian karyawan kontrak SPG menjadi karyawan tetap menggunakan sistem pendukung keputusan dengan metode SAW ini dapat dilakukan dengan mudah dan tepat, karena dihitung oleh sistem komputer
\end{abstract}

Kata Kunci : SPG, karyawan, sistem pendukung keputusan, simple additive weighting (SAW).

\begin{abstract}
In selecting and determining contract employees such as Sales Promotion Girl (SPG) to become permanent employees in a company, it still seems inaccurate, because the assessment and calculation of the results of the test are done manually, so there is a possibility of errors in providing the final results of the selection. Therefore, a Decision Support System was designed that could determine SPG contract employees to become permanent employees who could assist the company in selecting the right employees. Decision Support Systems are part of a computer-based information system that is commonly used to support decision making in an organization or company. This decision support system is designed using the Simple Additive Weighting $(S A W)$ method to calculate the results in determining SPG contract employees to become permanent employees. So, in the process of selecting SPG contract employees to become permanent employees using a decision support system using the SAW method can be done easily and precisely, because it is calculated by a computer system..
\end{abstract}

Keyword : SPG, employees, decision support systems, simple additive weighting $(S A W)$..

\section{PENDAHULUAN}

Sales Promotion Girl (SPG) yang bekerja pada CV. Indo Media Selular mempunyai status karyawan tidak tetap atau disebut kontrak. Dimana SPG tersebut dapat bekerja selama hubungan kerja sama pemegang merek handphone tersebut dengan CV. Indo Media Selular masih berjalan. Namun jika kerja sama telah berakhir, otomatis sesuai kesepakatan, SPG tersebut tidak dapat bekerja lagi pada CV. Indo Media Selular. Ada beberapa hal atau syarat serta kemungkinan seorang SPG dapat menjadi karyawan tetap pada CV. Indo Media Selular, salah satunya yaitu perusahaan tersebut memang membutuhkan seorang karyawan, serta adanya keinginan seorang SPG untuk bekerja menjadi karyawan tetap di CV. Indo Media Selular. Karena hal itu, tidak semua SPG dapat menjadi karyawan tetap harus ada penyeleksian dari seorang pimpinan perusahaan untuk dapat menerima seorang SPG tersebut[1].

Selama ini, penentuan karyawan kontrak menjadi karyawan tetap dilakukan secara objektif oleh pimpinan perusahaan tanpa ada penyeleksian sehingga karyawan yang terpilih sering kali tidak memenuhi kriteria yang dibutuhkan perusahaan, sehingga karyawan terpilih tersebut tidak dapat bekerja secara maksimal karena kurangnya kemampuan[2]. Dengan permasalahan tersebut maka, 
perlu adanya solusi yang dapat menangani hal tersebut dengan membuat suatu Sistem Pendukung Keputusan (SPK).

Salah satu metode yang dapat digunakan dalam pengambilan keputusan untuk menentukan status Sales Promotion Girl (SPG) menjadi karyawan tetap yaitu dengan metode Simple Additive Weighting (SAW). Metode SAW dikenal istilah metode penjumlahan terbobot. Konsep dasar metode SAW adalah mencari penjumlahan terbobot dari rating kinerja pada setiap alternatif pada semua atribut[3]-[5].

\section{METODOLOGI PENELITIAN}

Metode penelitian dilakukan untuk mencari sesuatu secara sistematis dengan menggunakan metode ilmiah serta sumber yang berlaku. Dalam proses penelitian ini ditunjukan ke semua pihak, terutama kepada pihak yang bertanggung jawab mengenai penerimaan SPG, sehingga dapat memberikan hasil yang diharapkan. Adapun metode penelitian yang digunakan dalam penelitian ini adalah sebagai berikut[6], [7]:

1. Pengumpulan data kepustakaan (Library Research) Tahap ini dilakukan dengan mencari keterangan dengan membaca buku-buku serta jurnal-jurnal yang bersifat teoritis yang mendukung penelitian ini.

2. Pengumpulan data lapangan (Field Research)

Tahap ini dilakukan dengan mengumpulkan data melalui riset dan sesi wawancara pada bagian Human Resource Development (HRD) pada CV.Indo Media Selular. Browsing (pencarian dan penjelajahan untuk mencari atau melihat sesuatu yang diinginkan) di internet.

3. Analisa

Merupakan proses analis terhadap permasalahan dan mendefinisikan model penyelesaian, termasuk dalam proses ini adalah melakukan analisis terhadap permasalahan yang akan diselesaikan.

4. Pembahasan

Tahap ini dilakukan pembahasan perhitungan pembobotan serta nilai kriteria-kriteria pada setiap alternatif untuk menentukan status karyawan kontrak SPG menjadi karyawan tetap mengunakan metode SAW.

5. Implementasi dan pengujian

Tahap ini melakukan implementasi sistem pendukung keputusan dan pengujian terhadap sistem yang telah dibuat.

\subsection{Sistem Pendukung Keputusan}

Konsep Sistem Penunjang Keputusan (SPK) muncul pertama kali pada awal 1970-an oleh ScottMorton, mereka mendefenisikan SPK sebagai suatu sistem interaktif berbasis komputer yang dapat membantu para pengambil keputusan dalam menggunakan data dan model untuk memecahkan persoalan yang bersifat tidak terstruktur[8], [9]. Dari definisi tersebut, dapat diindikasikan empat karakteristik utama dari SPK yaitu :

1. SPK menggabungkan data dan model menjadi satu bagian, SPK dirancang untuk membantu para manajer (pengambil keputusan) dalam proses pengambilan keputusan dari masalah yang bersifat semi struktural (tidak terstruktur.

2. SPK lebih cenderung dipandang sebagai penunjang penilaian manajer dan sama sekali bukan untuk menggantikannya.

3. Teknik SPK dikembangkan untuk meningkatkan efektivitas dari pengambil keputusan.

\subsection{Metode Simple additive Weighting (SAW)}

Metode SAW sering juga dikenal istilah metode penjumlahan terbobot. Konsep dasar metode SAW adalah mencari penjumlahan terbobot dari rating kinerja pada setiap alternatif pada semua atribut. Metode SAW membutuhkan proses normalisasi matriks keputusan (X) ke suatu skala yang 
dapat diperbandingkan dengan semua rating alternatif yang ada[10]-[12]. Berikut ini adalah rumus dari metode Simple Additive Weighting (SAW) :

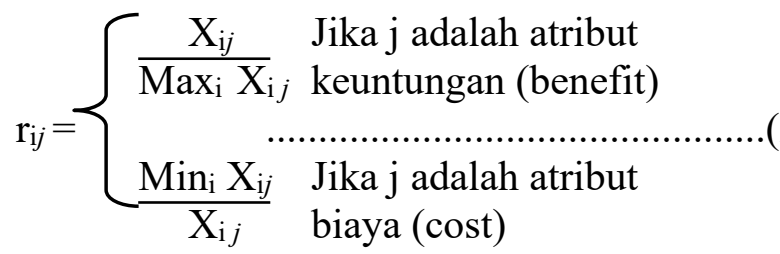

Keterangan :

$\mathrm{r}_{\mathrm{ij}} \quad=$ nilai rating kinerja ternormalisasi

$\mathrm{x}_{\mathrm{ij}} \quad=$ nilai atribut yang dimiliki dari setiap kriteria

Max $\mathrm{x}_{\mathrm{ij}}=$ nilai terbesar dari setiap kriteria

Min $\mathrm{x}_{\mathrm{ij}}=$ nilai terkecil dari setiap kriteria

benefit $=$ jika nilai terbesar adalah terbaik

cost $=$ jika nilai terkecil adalah terbaik

Dimana $r_{i j}$ sebagai rating kinerja ternormalisasi dari alternatif $A_{i}$ pada atribut $C_{j} ; i=1,2, \ldots, m$ dan $\mathrm{j}=1,2, \ldots, \mathrm{n}$. Nilai preferensi untuk setiap alternatif $\left(\mathrm{V}_{\mathrm{i}}\right)$ dapat dilihat pada persamaan 2.2 berikut ini. $\mathbf{V}_{i}=\sum w_{j} r_{i j}$

Keterangan :

$\mathrm{V}_{\mathrm{i}} \quad=$ ranking untuk setiap alternatif

$\mathrm{W}_{\mathrm{j}} \quad=$ nilai bobot dari setiap kriteria

$\mathrm{r}_{\mathrm{ij}} \quad=$ nilai rating kinerja ternormalisasi

Nilai $V_{i}$ yang lebih besar mengindikasikan bahwa alternatif $A_{i}$ lebih terpilih.

\subsection{Langkah Penyelesaian Metode SAW}

Adapun langkah-langkah penyelesaian masalah dengan metode SAW [13]adalah sebagai berikut

1. Menentukan kriteria-kriteria yang akan dijadikan acuan dalam pengambilan keputusan, yaitu Ci.

2. Menentukan rating kecocokan setiap alternatif pada setiap kriteria.

3. Membuat matriks keputusan berdasarkan kriteria (Ci), kemudian melakukan normalisasi matriks berdasarkan persamaan yang disesuaikan dengan jenis atribut (atribut keuntungan ataupun atribut biaya) sehingga diperoleh matriks ternormalisasi $\mathrm{R}$.

4. Hasil akhir diperoleh dari proses perankingan yaitu penjumlahan dari perkalian matriks ternormalisasi $\mathrm{R}$ dengan vektor bobot sehingga diperoleh nilai terbesar yang dipilih sebagai alternatif terbaik (Ai) sebagai solusi.

\subsection{Analisa Masalah}

\section{HASIL DAN PEMBAHASAN}

Setelah masa kerja kontrak Sales Promotion Girl (SPG) berakhir, maka beberapa SPG mengajukan diri ingin menjadi karyawan tetap pada CV. Indo Media Selular. Maka dari itu, perusahaan akan melakukan penyeleksian terhadap SPG yang ingin bekerja dan menjadi karyawan tetap. Pada analisa masalah ini, penulis akan menguraikan bagaimana proses menentukan status karyawan kontrak SPG menjadi karyawan kontrak dengan metode Simple Additive Weighting (SAW).

\subsection{Contoh Kasus}

Terdapat 4 orang SPG yang ingin menjadi karyawan tetap pada CV. Indo Media Selular. Dan posisi yang ada akan ditempatkan yaitu sebagai Costumer Service. 4 orang yang menjadi kandidat (Alternatif) tersebut adalah sebagai berikut : 
A1 = Dewi; A2 = Maya; $\quad$ A3 = Rani; A4 = Mutia.

Ada lima kriteria yang digunakan untuk melakukan penilaian yaitu :

$\mathrm{C} 1=$ Kinerja

: Sangat Baik

$\mathrm{C} 2=$ Kedisiplinan

: Baik

$\mathrm{C} 3=$ Loyalitas

: Baik

C4=Pengalaman Bekerja

$\mathrm{C} 5=$ Ujian Komputer

: Cukup

: Cukup

Pengambil keputusan memberikan bobot untuk setiap kriteria sebagai berikut :

$\mathrm{C} 1=35 \% ; \mathrm{C} 2=25 \% ; \mathrm{C} 3=25 \% ; \mathrm{C} 4=15 \% ; \mathrm{C} 5=15 \%$.

\subsection{Perhitungan Menentukan Status Karyawan}

Ada beberapa langkah untuk melakukan perhitungan menentukan status karyawan kontrak Sales Promotion Girl (SPG) menjadi karyawan tetap menggunakan metode SAW sesuai contoh kasus diatas yaitu :

1. Langkah Pertama memberikan nilai dan bobot untuk setiap alternatif pada setiap kriteria yang sudah ditentukan.

Tabel 1. Nilai dan Bobot untuk Kriteria

\begin{tabular}{|c|c|c|l|}
\hline \multicolumn{5}{|c|}{ C1-C3 dan C5 } \\
\hline Nilai Tertulis & Bobot & Nilai Kriteria & Keterangan \\
\hline $80-100$ & $35 \%$ & 5 & Sangat Baik \\
\hline $60-79$ & $25 \%$ & 4 & Baik \\
\hline $40-59$ & $15 \%$ & 3 & Cukup \\
\hline $20-39$ & $5 \%$ & 2 & Buruk \\
\hline $0-19$ & $0 \%$ & 1 & Sangat Buruk \\
\hline
\end{tabular}

Untuk nilai Pengalaman Bekerja (C4) bisa dilihat pada Tabel 2.

Tabel 2. Pengalaman Bekerja (C4)

\begin{tabular}{|l|c|}
\hline Pengalaman Bekerja & Nilai \\
\hline$>4$ Tahun Keatas & 5 \\
\hline$>3$ Tahun & 4 \\
\hline$>2$ Tahun & 3 \\
\hline$>1$ Tahun & 2 \\
\hline$<=1$ Tahun & 1 \\
\hline
\end{tabular}

2. Langkah kedua, menentukan rating kecocokan dari setiap alternatif, seperti terlihat berikut.

Tabel 3. Rating Kecocokan

\begin{tabular}{|l|c|c|c|c|c|}
\hline \multirow{2}{*}{ Alternatif } & \multicolumn{5}{|c|}{ Hasil Penilaian } \\
\cline { 2 - 6 } & C1 & C2 & C3 & C4 & C5 \\
\hline Dewi & 75 & 85 & 75 & 2 & 77 \\
\hline Maya & 95 & 90 & 75 & 3 & 70 \\
\hline Rani & 80 & 70 & 65 & 2 & 75 \\
\hline Mutia & 85 & 75 & 85 & 2.5 & 86 \\
\hline
\end{tabular}

3. Langkah ketiga pembentukan matriks keputusan dibentuk dari Tabel 4.3 sebagai berikut :

$$
x=\left[\begin{array}{lllll}
4 & 5 & 4 & 2 & 4 \\
5 & 5 & 4 & 3 & 4 \\
5 & 4 & 4 & 2 & 4 \\
5 & 4 & 5 & 3 & 5
\end{array}\right]
$$


4. Langkah keempat hitung nilai normalisasi dari setiap alternatif dengan rumus sebagai berikut :

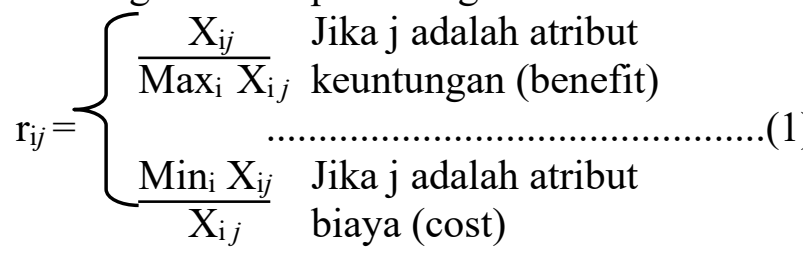

Normalisasi :

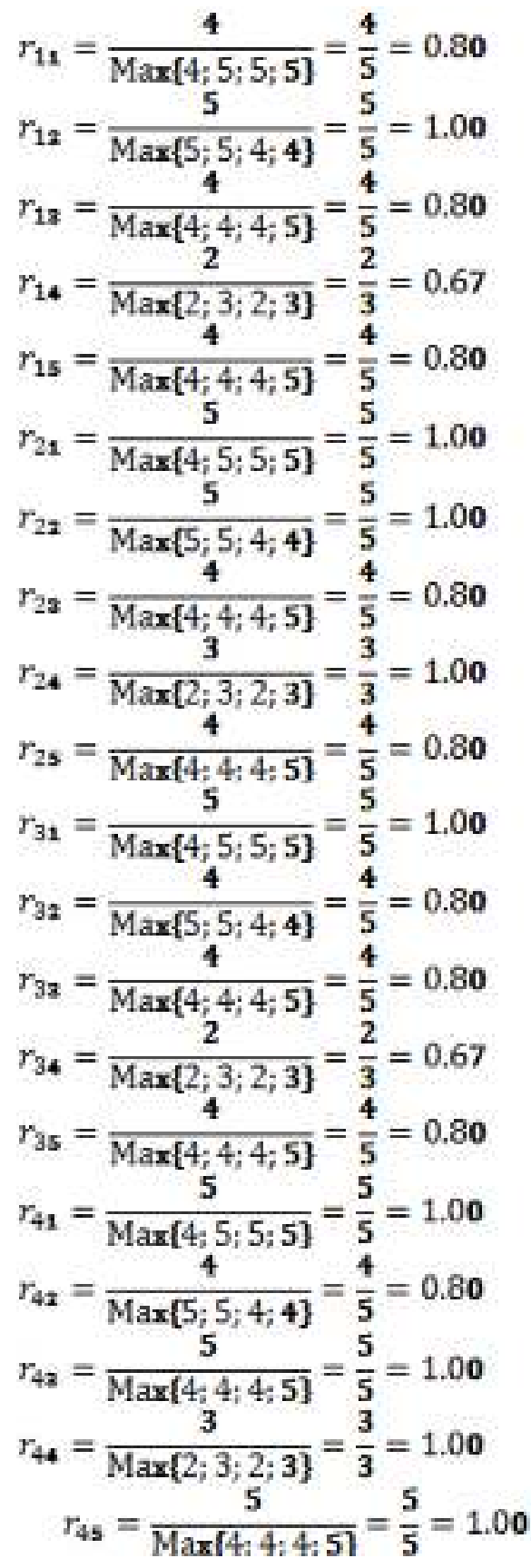

Kemudian hasil normalisasi dibuat dalam matriks normalisasi :

$R=\left[\begin{array}{lllll}0.80 & 1.00 & 0.80 & 0.67 & 0.80 \\ 1.00 & 1.00 & 0.80 & 1.00 & 0.80 \\ 1.00 & 0.80 & 0.80 & 0.67 & 0.80 \\ 1.00 & 0.80 & 1.00 & 1.00 & 1.00\end{array}\right]$

5. Langkah kelima tentukan bobot yang akan digunakan untuk proses perankingan : 


$$
w=\left[\begin{array}{lllll}
0.35 & 0.25 & 0.25 & 0.15 & 0.15
\end{array}\right]
$$

6. Langkah keenam pencarian perankingan atau nilai terbaik dengan memasukan setiap kriteria yang diberikan dengan menggunakan rumus:

$$
\mathbf{V}_{i}=\sum w_{j} r_{i j}
$$

Maka hasil perankingan adalah sebagai berikut :

$\mathrm{V}_{1}=(0.35)(0.80)+(0.25)(1.00)+(0.25)(0.80)+(0.15)(0.67)+(0.15)(0.80)=\mathbf{0 . 9 5}$

$\mathrm{V}_{2}=(0.35)(1.00)+(0.25)(1.00)+(0.25)(0.80)+(0.15)(1.00)+(0.15)(0.80)=\mathbf{1 . 0 7}$

$\mathrm{V}_{3}=(0.35)(1.00)+(0.25)(0.80)+(0.25)(0.80)+(0.15)(0.67)+(0.15)(0.80)=\mathbf{0 . 9 7}$

$\mathrm{V}_{4}=(0.35)(1.00)+(0.25)(0.80)+(0.25)(1.00)+(0.15)(1.00)+(0.15)(1.00)=\mathbf{1 . 1 0}$

Di antara $V_{1}, V_{2}, V_{3}$ dan $V_{4}$ dengan nilai terbesar adalah $V_{2}$, sehingga kandidat (alternatif) yang terpilih dan berhak untuk menjadi karyawan tetap CV. Indo Media Selular untuk mengisi posisi sebagai Costumer Service yaitu $\mathbf{V}_{\mathbf{4}}=$ Mutia.

\subsection{Implementasi}

Form ini digunakan untuk melakukan pengisian data karyawan kontrak SPG yang ada di perusahaan. Data karyawan yang diisi berupa kode, nama, alamat serta pendidikan terakhir karyawan kontrak SPG. Adapun tampilan form isiannya terlihat pada Gambar 1 di bawah ini.

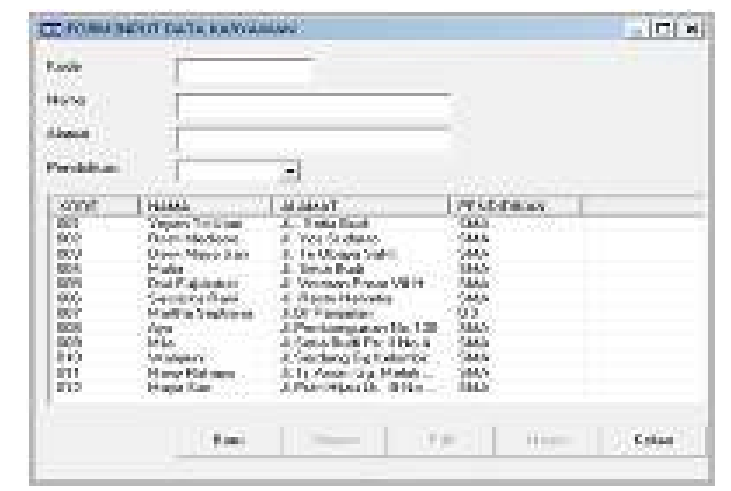

\section{Gambar 1. Form Input Data Karyawan}

Form ini digunakan untuk memasukkan nilai yang didapat karyawan kontrak SPG dari setiap kriteria yang telah ditentukan perusahaan. Adapun tampilan form isiannya dapat dilihat pada Gambar 2.

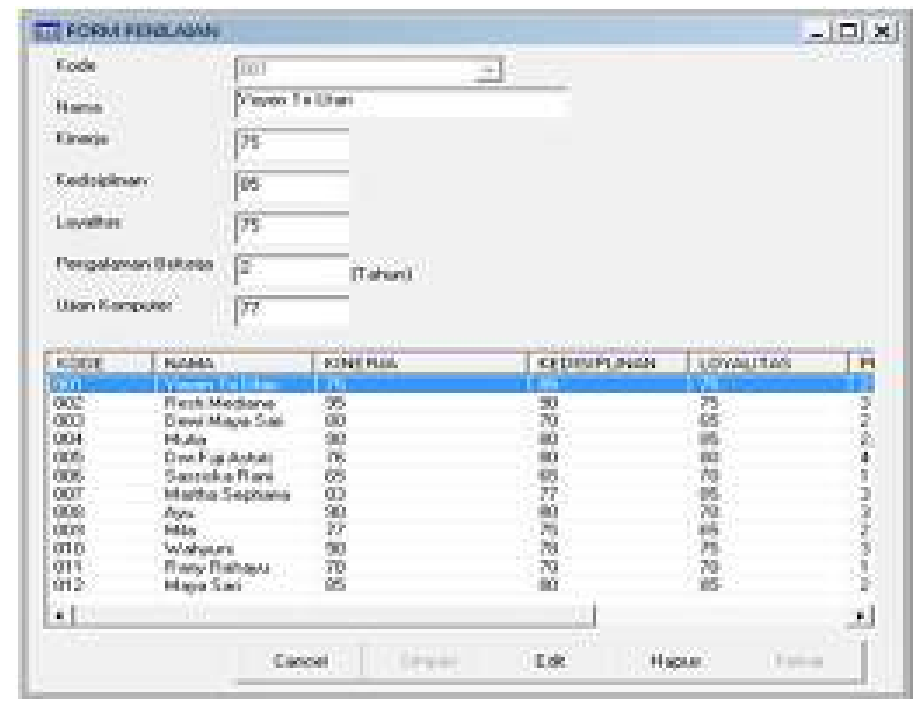

Gambar 2. Form Penilaian 
Form ini digunakan untuk memberikan berapa besar persen bobot untuk setiap kriteria yang ada. Adapun tampilannya dapat dilihat pada Gambar 3. di bawah ini.

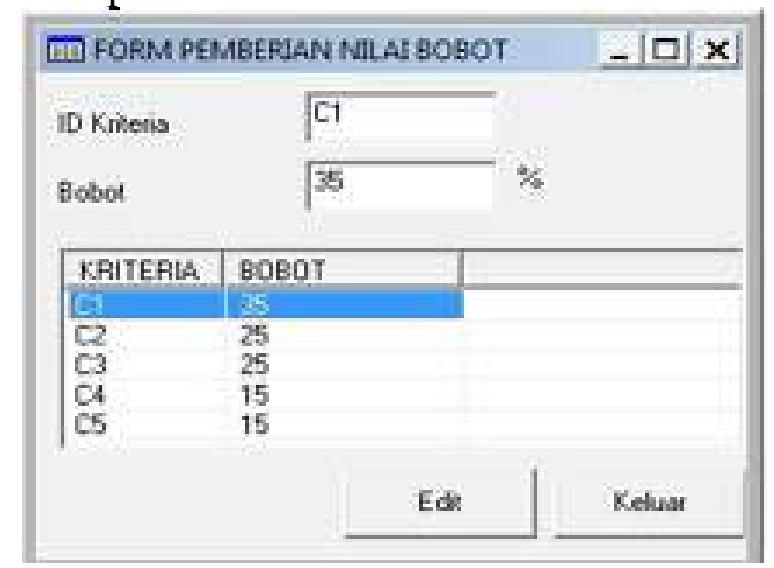

Gambar 3. Form Pemberian Nilai Bobot

Form ini menampilkan nilai-nilai yang telah dimasukkan kedalam sistem, yang selanjutnya akan dilakukan proses perankingan, sehingga dapat dilihat siapa yang mendapatkan nilai tertinggi dan berhak lolos sebagai karyawan tetap pada CV. Indo Media Selular. Adapaun tampilannya dapat dilihat pada Gambar 4.

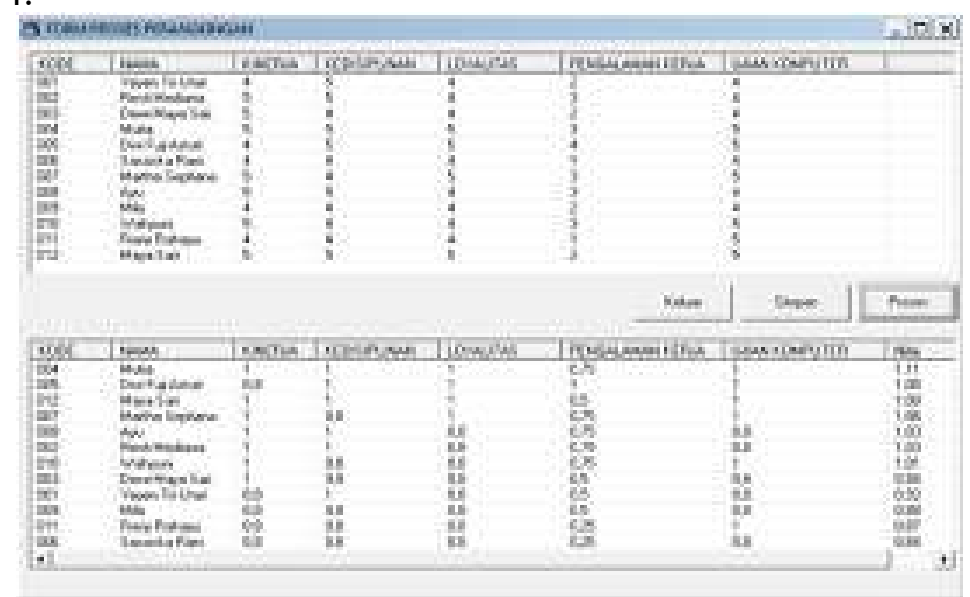

Gambar 4. Form Proses Perankingan

\section{KESIMPULAN}

Berdasarkan hasil penelitian yang telah dilakukan menghasilkan sebuah perangkat lunak (software) yang dapat menentuka SPG kontrak menjadi tetap dengan menggunakan Metode SAW. Selama proses perancangan dan implementasi program aplikasi dapat diambil kesimpulan sebagai berikut:

1. Prosedur seleksi menentukan status karyawan kontrak Sales Promotion Girl (SPG) menjadi karyawan tetap, dimulai dari SPG yang mengajukan diri dan ingin bekerja sebagai karyawan tetap di CV.Indo Media Selular. Selanjutnya mengisi formulir data diri, kemudian akan dilakukan seleksi dengan penilaian dari beberapa aspek seperti kinerja, loyalitas, kedisiplinan, pengalaman bekerja dan terakhir dilakukan tes ujian komputer.

2. Metode Simple Additive Weighting (SAW) diterapkan dalam sistem pendukung keputusan, untuk menghitung serta memberikan hasil akhir penilaian yang telah dirankingkan sehingga dapat menentukan karyawan kontrak SPG menjadi karyawan tetap dengan tepat.

3. Sistem Pendukung Keputusan (SPK) ini dirancang dengan sistem komputerisasi menggunakan program Visual basic 6.0 serta database dengan menggunakan Microsoft Access 2007. 


\section{DAFTAR PUSTAKA}

[1] A. Octa, "Sales Promotion Girls - SPG," DISTRIBUSI PEMASARAN, Oct. 2020. https://distribusipemasaran.com/sales-promotion-girls-pengertian-fungsi-dan-tugas-jobsdeskspg/ (accessed May 29, 2021).

[2] I. Karlina, "10 Tugas SPG Perusahaan, Tanggung Jawab, Gaji \& Kualifikasi," tugaskaryawan.com, May 2021. https://tugaskaryawan.com/tugas-spg/ (accessed May 29, 2021).

[3] F. Yanti and T. Limbong, "Sistem Pendukung Keputusan Pemilihan Lembaga Bimbingan Belajar Berdasarkan Pendapatan Orang Tua dengan Metode Simple Additive Weighting," JUKI : Jurnal Komputer dan Informatika, vol. 2, 2020.

[4] T. Limbong, "IMPLEMENTASI METODE SIMPLE ADDITIVE WEIGHTING (SAW) UNTUK PEMILIHAN PEKERJAAN BIDANG INFORMATIKA," Proceeding SNIKOM, vol. 3, no. 5, pp. 6-7, 2013.

[5] F. Yanti and T. Limbong, "Sistem Pendukung Keputusan Pemilihan Lembaga Bimbingan Belajar Berdasarkan Pendapatan Orang Tua dengan Metode Simple Additive Weighting," JUKI : Jurnal Komputer dan Informatika, Nov. 23, 2020. https://ioinformatic.org/index.php/JUKI/article/view/32 (accessed May 29, 2021).

[6] S. Suryabrata, "Metodelogi penelitian," Jakarta: Raja Grafindo Persada, 1998.

[7] S. Arikunto, "Metodelogi penelitian," Yogyakarta: Bina Aksara, 2006.

[8] T. Limbong et al., Sistem Pendukung Keputusan: Metode \& Implementasi. Yayasan Kita Menulis, 2020.

[9] Kusrini, Konsep dan Aplikasi Sistem Pendukung Keputusan. 2007.

[10] A. Rikki, M. Maebun, and J. R. Siregar, "Sistem Pendukung Keputusan Penerimaan Karyawan Dengan Metode SAW Pada PT. Karya Sahata Medan," Journal of Informatics Pelita Nusantara, 2016.

[11] F. Sonata, "Implementasi Metode Simple Additive Weighting (Saw) dengan Proses Fuzzifikasi dalam Penilaian Kinerja Dosen," Jurnal Teknologi Informasi dan Komunikasi, vol. 5, no. 2, pp. 71-80, 2016.

[12] P. M. Hasugian, "Perancangan Sistem Pendukung Keputusan Dalam Menentukan Dosen Berprestasi Dengan Metode Simple Additive Weighting," Journal Of Informatic Pelita Nusantara, 2019.

[13] D. Nofriansyah and S. Defit, Multi Criteria Decision Making (MCDM) pada Sistem Pendukung Keputusan. Deepublish, 2017. 